Lense, G. H. E., Moreira, R. S., Bócoli, F. A., Parreiras, T. C., Teodoro, A. E. de M., Spalević, V., Mincato, R. L. (2020): Soil organic matter loss by water erosion in a coffee organic farm. Agriculture and Forestry, 66 (2): $45-$ 50.

DOI: 10.17707/AgricultForest.66.2.04

Guilherme Henrique Expedito LENSE ${ }^{I}$, Rodrigo Santos MOREIRA', Fernanda Almeida BÓCOLI ${ }^{2}$, Taya Cristo PARREIRAS ${ }^{1}$, Alexandre Elias de Miranda TEODORO ${ }^{I}$, Velibor SPALEVIC ${ }^{3}$, Ronaldo Luiz MINCATO ${ }^{I}$

\title{
SOIL ORGANIC MATTER LOSS BY WATER EROSION IN A COFFEE ORGANIC FARM
}

\section{SUMMARY}

In tropical regions, water erosion is the process responsible for the redistribution and the loss of soil organic matter (SOM). Modelling can provide a diagnosis of the dynamics of SOM in agricultural production systems, and assist the proposing of conservationist measures. Therefore, this work aimed to estimate SOM losses due to water erosion in an agricultural production system, through the use of modelling techniques. The study area corresponding to the Santo André Farm, located in south-eastern Brazil.

The area of the farm is around $75 \mathrm{ha}$, and the main agricultural product is coffee $(78 \%)$. The modelling was performed based on the SOM content of the area, and the estimated soil losses, according to the Revised Universal Soil Loss Equation.

To the SOM determination, soil samples were collected at 20 points, distributed over the area, in the surface layer $(0-20 \mathrm{~cm})$, in March 2018.

The parameter acquiring and the data analysis were performed using remote sensing techniques and a Geographic Information System, which was also used to interpolate the SOM content, through the use of the ordinary kriging. The organic matter content on the farm ranged from 1.20 to $2.46 \%$, while the average soil loss was $25.70 \mathrm{Mg} \mathrm{ha}^{-1}$ year $^{-1}$, with higher erosion rates in steepest sites. The estimated loss of total organic matter at $31.87 \mathrm{Mg}$ year $^{-1}$, with an average of 0.42 $\mathrm{Mg} \mathrm{ha}^{-1}$ year $^{-1}$. The observed results reveal the need to implement conservationist management measures to reduce soil losses, and the consequent SOM losses.

\footnotetext{
${ }^{1}$ Ronaldo Luiz Mincato (corresponding author: ronaldo.mincato@unifal-mg.edu.br), Guilherme Henrique Expedito Lense, Rodrigo Santos Moreira, Taya Cristo Parreiras, Alexandre Elias de Miranda Teodoro, Universidade Federal de Alfenas - UNIFAL-MG, Alfenas, Minas Gerais, BRAZIL.

${ }^{2}$ Fernanda Almeida Bócoli, Universidade Federal de Lavras - UFLA, Lavras, Minas Gerais, BRAZIL.

${ }^{3}$ Velibor Spalević, University of Montenegro, Faculty of Philosophy, Geography, Niksic, MONTENEGRO.

Paper presented at the GEA (Geo Eco-Eco Agro) International Conference 2020, Podgorica.

Notes: The authors declare that they have no conflicts of interest. Authorship Form signed online.

Received:17/04/2020

Accepted:25/05/2020
} 
Keywords: Soil conservation, Soil losses, RUSLE, Agricultural sustainability, Kriging

\section{INTRODUCTION}

Soil organic matter (SOM) improves the structure and fertility of the soil and, consequently, increases agricultural productivity. Moreover, changes in SOM contents result in a significant variation in soil carbon stock and can affect the $\mathrm{CO}_{2}$ atmospheric concentration (Lal, 2004; 2006).

Soil erosion by water is considered as a serious environmental threat (Spalevic, 2011; Spalevic et al. 2012; Nikolic et al. 2019; Chalise et al., 2019; Khaledi Darvishan et al., 2019; Ouallali et al., 2020). Water erosion can breakdown the soil structure and expose the SOM to the climatic conditions and the attack of microbial enzymes (Hancock et al., 2019; Lal, 2019). For this reason, it is an important process responsible for the carbon losses, especially in tropical and subtropical soils, due to the rainfall and temperature conditions.

In this context, the assessment of SOM dynamics in agricultural production systems is necessary to propose conservationist practices capable of mitigating the carbon losses by water erosion and, consequently, decrease the greenhouse gas emissions from agricultural soils.

Water erosion modeling can be used to simulate the erosion process and to measure the SOM losses based on factors such as climate, relief, physical characteristics of the soil, and vegetation cover with the advantages of being a simple and inexpensive method. Modeling reduces the limitations found in the direct quantification of water erosion and SOM loss, which is an expensive process that requires field experiments with continuous long-term data collections (Starr et al., 2000; Barros et al., 2018).

Based on this information, the objective of this work was to estimate the soil organic matter loss by water erosion in a coffee agricultural production system.

\section{MATERIAL AND METHODS}

The prevailing odour from an established production unit was detected from Study area. The study area was located at Santo André Farm in the Municipality of Divisa Nova, south of Minas Gerais, at coordinates UTM 377066 at $378515 \mathrm{~m} \mathrm{O}$ and 7621721 at $7622954 \mathrm{~m} \mathrm{~S}$, zone 23K, Datum SIRGAS 2000 (Figure 1).

The farm has an area of 75 ha, predominantly cultivated with coffee (78\%), followed by pasture (12\%), access roads (6\%), drainage (2\%), and facilities (2\%). Coffee is grown under organic cultivation system, with conservationist practices, such as the management of spontaneous vegetation between the coffee tree rows and level planting. The land use map was prepared using ArcMap 10.5 software (ESRI, 2015), based on high-resolution images from the Basemap tool (ESRI, 2015) and field surveys. The soil was classified as Ferralsol (WRB, 2015) and the climate according to the Köppen classification as Tropical Mesothermal (Cwb), with annual precipitation of $1500 \mathrm{~mm}$ and an average temperature around $22^{\circ} \mathrm{C}$ (Alvares et al., 2013). 


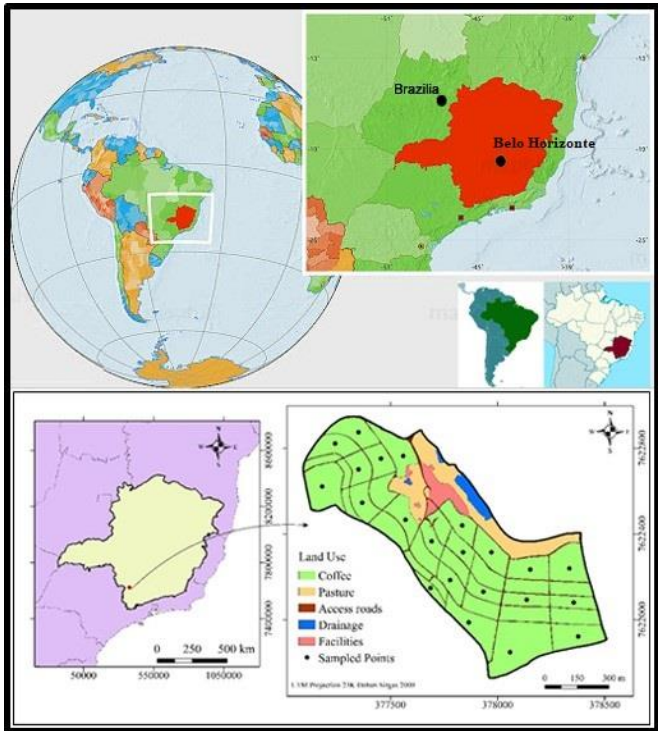

Figure 1. Location and land use of Santo André Farm, Municipality of Divisa Nova, South of Minas Gerais, Southeastern Brazil.

Soil organic matter loss. We estimate the SOM loss by water erosion using the Revised Universal Soil Loss Equation (Renard et al., 1997) according to Equation 1 and the organic matter content in the area, according to Starr, et al. (2000).

$$
\mathrm{A}=\mathrm{R} \times \mathrm{K} \times \mathrm{LS} \times \mathrm{C} \times \mathrm{P}
$$

Equation 1

where, $\mathrm{A}=$ average annual soil loss, in $\mathrm{Mg} \mathrm{ha}^{-1}$ year $^{-1} ; \mathrm{R}=$ rainfall erosivity factor, in $\mathrm{MJ} \mathrm{mm} \mathrm{ha}{ }^{-1} \mathrm{~h}^{-1}$ year ${ }^{-1} ; \mathrm{K}=$ soil erodibility factor, in $\mathrm{Mg} \mathrm{ha}{ }^{-1} \mathrm{MJ}^{-1} \mathrm{~mm}^{-1}$; $\mathrm{LS}=$ topographic factor, given by the relationship between length (L) and inclination of the relief $(\mathrm{S})$, dimensionless; $\mathrm{C}=$ cover and management factor, dimensionless; and $\mathrm{P}=$ conservation practices factor, dimensionless.

The $\mathrm{R}$ factor was $6700 \mathrm{MJ} \mathrm{mm} \mathrm{ha}^{-1} \mathrm{~h}^{-1}$ year $^{-1}$, determined based on the erosivity map of Minas Gerais (Aquino et al., 2012). The $\mathrm{K}$ factor represents the soil resistance to erosion. We adopt the erodibility value of $0.026 \mathrm{Mg} \mathrm{ha}^{-1} \mathrm{MJ}^{-1}$ $\mathrm{mm}^{-1}$ to the Latosols of the area, according to Tavares, et al. (2019).

We calculated the LS factor according to the topography of the area using the digital elevation model (DEM) (Miranda et al., 2005) based on the methodology of Moore and Burch (1986) (Equation 2). The LS values ranged from 0 to 26.3, with an average of 2.14.

$$
\mathrm{LS}=\left(\frac{\mathrm{FA}-10}{22,13}\right)^{0.4} \cdot\left(\frac{\sin (\mathrm{S})}{0.0896}\right)^{1.3}
$$

Equation 2

where, LS is the topographic factor, dimensionless; FA is the accumulation of flow expressed as the number of cells in the DEM grid; $S$ is the hydrographic basin declivity in degree; and 10 is the spatial resolution of the DEM, in meters. 
The average $\mathrm{C}$ factor was 0.17 , indicating good vegetation cover. This parameter ranges from 0 to 1 according to the vegetation cover of the area, with higher values associated with sites with low vegetation density. The $\mathrm{C}$ factor was determined using the Durigon, et al. (2014), which is based on the normalized difference vegetation index (NDVI) (Equation 3).

$$
\mathrm{C}_{\mathrm{r}}=\frac{-\mathrm{NDVI}+1}{2}
$$

Equation 3

where $\mathrm{C}_{\mathrm{r}}=$ soil covered factor e NDVI $=$ normalized difference vegetation index, both dimensionless.

NDVI is a widely used indicator of vegetation vigor. This index ranges from -1 to +1 , where the closer the value is to +1 the higher the plant density. The index was calculated according to Tucker (1979); using images from the Landsat8 Operational Land Imager (OLI) satellite, bands 4 and 5, orbit/point 219/75, obtained from the Image Generation Division (INPE, 2019).

Finally, the $\mathrm{P}$ factor, which represents the influence of management practices on the erosion process, ranges from 0 to 1 . Due to the conservationist practices, we adopted a value of 0.5 .

To determine soil organic matter (SOM) contents, we collected soil from the superficial layer $(0-20 \mathrm{~cm})$ in 20 points distributed in the subbasin (Figure 1A), and both SOM and soil density (Ds) were estimated according to Embrapa (2017). The collection of the samples was carried out in March 2018. The SOM contents were interpolated by the ordinary kriging method using the Geostatistical Analyst tool from the ArcMap 10.5 software (ESRI, 2015).

\section{RESULTS AND DISCUSSION}

The soil organic matter showed spatial dependence in the area, with the exponential model fitted, generating an $\mathrm{R}^{2}$ of 0.92 . The SOM contents ranged from 1.20 to $2.46 \%$, with higher levels founded mainly in coffee (Figure 1B). The management of spontaneous vegetation and organic fertilization may have been the reason for the high SOM content in areas with coffee cultivation.

The average soil loss was quantified at $25.70 \mathrm{Mg} \mathrm{ha}^{-1}$ year $^{-1}$, with higher water erosion intensity in slope areas, and sites with low plant density (Figure 2A). The average soil loss is considered high for the study conditions (> 15.00 $\mathrm{Mg} \mathrm{ha}^{-1}$ year $^{-1}$ ), according to Avanzi, et al. (2013), indicating the necessity for a comprehensive management plan seeking to reduce erosion rates at Santo André Farm. It is worth mentioning that, in the short term, areas with higher levels of erosion (Figure 1A) should be prioritized to the adoption of mitigation measures.

The total SOM loss was $31.87 \mathrm{Mg}$ year $^{-1}$, with an average of $0.42 \mathrm{Mg} \mathrm{ha}^{-1}$ year $^{-1}$. As expected, the highest rates of SOM loss occurred in areas with severe erosion (Figure 2C). Considering that coffee is cultivated in an organic system, any SOM loss results in several damages to the soil and causes additional costs to the producer by replacing the nutrients and organic matter lost contents, seeking to guarantee a satisfactory soil fertility level. 

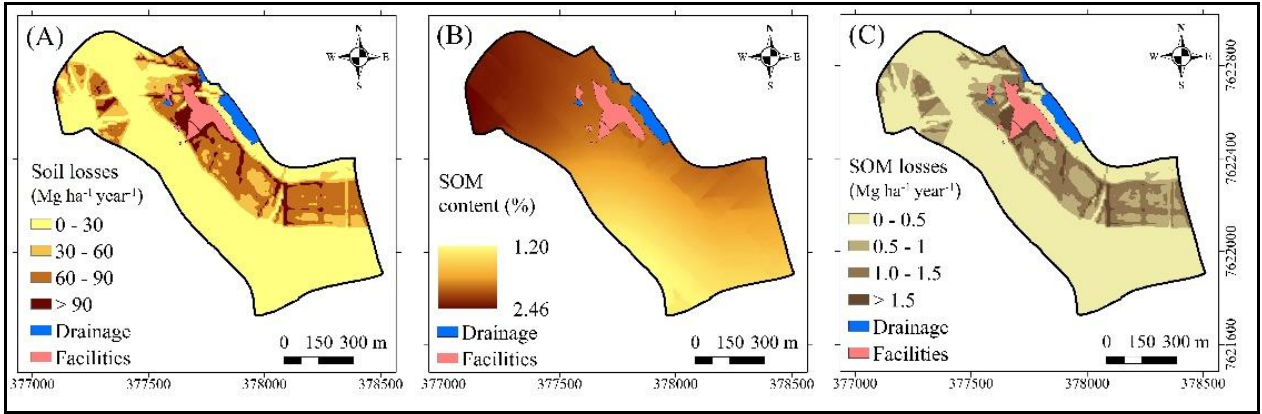

Figure 2. Soil losses (A), SOM content (B) and SOM losses (C) from Santo André Farm, Municipality of Divisa Nova, south of Minas Gerais, Brazil. Notes: SOM: Soil Organic

Matter.

Controlling water erosion is a key mechanism for SOM loss mitigation and enhance soil carbon sequestration. According to Rimal and Lal (2009), SOM loss can be mitigated by the adoption of sustainable land management practices, such as no-till, level planting, and satisfactory soil vegetation cover. These practices can improve soil aggregation, improve water infiltration, and decrease runoff. Thus, the farm must adopt conservationist practices to reduce the SOM loss to minimum rates and guarantee the sustainability of the production system.

\section{CONCLUSIONS}

The soil organic matter content on the farm ranged from 1.20 to $2.46 \%$. The average soil loss was $25.70 \mathrm{Mg} \mathrm{ha}^{-1}$ year $^{-1}$, with higher erosion rates in high declivity areas. The methodology used to estimate the total organic matter loss at 31.87 $\mathrm{Mg}$ year $^{-1}$ with an average of $0.42 \mathrm{Mg} \mathrm{ha}^{-1}$ year $^{-1}$. The approach provided satisfactory results, which are useful in farm management planning.

\section{ACKNOWLEDGEMENTS}

To the Fundação de Amparo à Pesquisa do Estado de Minas Gerais (FAPEMIG), for the scholarship offered to the first author. To the Coordenação de Aperfeiçoamento de Pessoal de Nível Superior (CAPES), for the financing of the study - Financial Code 001.

\section{REFERENCES}

Alvares, C.A., Stape, J.L., Sentelhas, P.C. Gonçalves, J.L.M. and Sparovek, G. (2013): Köppen's climate classification map for Brazil. Meteorologische Zeitschrift, 22:711728.

Aquino, R.F., Silva, M.L.N., Freitas, D.A.F., Curi, N., Mello, C.R. and Avanzi, J.C. (2012): Spatial variability of the rainfall erosivity in southern region of Minas Gerais state, Brazil. Ciência e Agrotecnologia, 36:533-542.

Avanzi J.C., Silva, M.L.N., Curi, N., Norton, L.D., Beskow, S. and Martins, S.G. (2013): Spatial distribution of water erosion risk in a watershed with eucalyptus and Atlantic Forest. Ciência e Agrotecnologia, 37:427-434.

Barros, E.N.S., Viola, M.R., Rodrigues, J.A.M,, Mello, C.R., Avanzi, J.C. and Alves, M.V.G. (2018): Modelagem da erosão hídrica nas bacias hidrográficas dos rios Lontra e Manoel Alves Pequeno, Tocantins. Revista Brasileira de Ciências Agrárias, 13:1-9. 
Chalise, D.; Kumar, L.; Spalevic, V.; Skataric, G. (2019): Estimation of Sediment Yield and Maximum Outflow Using the IntErO Model in the Sarada River Basin of Nepal. Water 2019, 11, 952. doi:10.3390/w11050952

Durigon, V.L., Carvalho, D.F., Antunes, M.A.H., Oliveira, P.T.S. and Fernandes, M.M. (2014): NDVI time series for monitoring RUSLE cover management factor in a tropical watershed. International Journal of Remote Sensing, 35:441-453.

Embrapa (2017): Manual de métodos de análise do solo. Empresa Brasileira de Pesquisa Agropecuária. 3. ed. rev. Brasília, Embrapa.

ESRI (2015): ARCGIS Professional GIS for the desktop version 10.3. Environmental Systems Research Institute. Redlands, Califórnia, EUA, Software.

Hancock, G.R., Kunkel, T., Wells, T. and Martinez, C. (2019): Soil organic carbon and soil erosion - Understanding change at the large catchment scale. Geoderma, 343:60-71.

INPE (2019): Divisão de Geração de Imagens (DIDGI). Instituto Nacional de Pesquisas Espaciais, Ministério da Ciência, Tecnologia, Inovações e Comunicações. (also available at www.dgi.inpe.br/catalogo/).

Khaledi Darvishan, A., Mohammadi, M., Skataric, G., Popovic, S., Behzadfar, M., Rodolfo Ribeiro Sakuno, N., Luiz Mincato, R., Spalevic, V. (2019): Assessment of soil erosion, sediment yield and maximum outflow, using IntErO model (Case study: S8-IntA Shirindarreh Watershed, Iran). Agriculture and Forestry, 65 (4), 203-210

Lal, R. (2004): Soil carbon sequestration to mitigate climate change. Geoderma, 123:1-22.

Lal, R. (2006): Enhancing crop yields in the developing countries through restoration of the soil organic carbon pool in agricultural lands. Land Degradation \& Development, 17:197-209.

Lal, R. (2019): Accelerated Soil erosion as a source of atmospheric $\mathrm{CO}_{2}$. Soil Tillage Research, 188:35-40.

Miranda, E.E. (2005): Brasil em Relevo. Campinas: Embrapa Monitoramento por Satélite.

Moore, I.D., Burch, G.J. (1986): Physical basis of the length slope factor in the Universal Soil Loss Equation. Soil Science Society of America, 50:1294-1298.

Nikolic, G., Spalevic, V., Curovic, M., Khaledi Darvishan, A., Skataric, G., Pajic, M., Kavian, A., \& Tanaskovik, V. (2019): Variability of Soil Erosion Intensity Due to Vegetation Cover Changes: case Study of Orahovacka Rijeka, Montenegro. Notulae Botanicae Horti Agrobotanici Cluj-Napoca, 47 (1), 237-248. doi:10.15835/nbha47111310

Ouallali, A., Aassoumi, H., Moukhchane, M., Moumou, A., Houssni, M., Spalevic, V., \& Keesstra, S. (2020): Sediment mobilization study on Cretaceous, Tertiary and Quaternary lithological formations of an external Rif catchment, Morocco. Hydrological Sciences Journal. doi:10.1080/02626667.2020.1755435

Renard, K.G., Foster, G.R., Weesier, G.A., Mccool, D.K., Yoder, D.C. (1997): Predicting soil erosion by water: a guide to conservation planning with the Revised Universal Soil Loss Equation (RUSLE). Washington, United States Department of Agriculture.

Rimal, B.K., Lal, R. (2009): Soil and carbon losses from five different land management areas under simulated rainfall. Soil and Tillage Research, 106:62-70.

Spalevic, V., (2011): Impact of land use on runoff and soil erosion in Polimlje. Doctoral thesis. Faculty of Agriculture of the University of Belgrade, Serbia, p. 1-260.

Spalevic, V., Curovic, M., Borota, D., Fustic, B. (2012): Soil erosion in the river basin Zeljeznica, area of Bar, Montenegro.Agriculture and Forestry, 54(1-4), 5-24

Starr, G.C., Lal, R., Malone, R., Hothem, D., Owens, L., Kimble, J. (2000). Modeling soil carbon transported by water erosion processes. Land degradation \& Development, 11:83-91.

Tavares, A.S., Spalevic, V., Avanzi, J.C., Nogueira, D.A., Silva, M.L.N., Mincato, R.L. (2019): Modeling of water erosion by the erosion potential method in a pilot subbasin in southern Minas Gerais. Semina-Ciências Agrárias, 40:555-572.

Tucker, C.J. (1979): Red e Photographic infravermelho 1, combinações próximas para monitorar a vegetação. Sensoriamento Remoto do Meio Ambiente, 8:127-150.

WRB (2015): International soil classification system for naming soils and creating legends for soil maps. World reference base for soil resources, Update. Rome, Food and Agriculture Organization of the United Nations. 203p. 